\title{
Diallel Analysis of Barley Resistance to Blumeria graminis
}

\author{
M.I.E. Arabi*, E. Al-ShehadAh and M. JaWhar \\ Department of Molecular Biology and Biotechnology, AECS, P. O. Box 6091, Damascus, Syria \\ (Received 12 August 2018; Accepted 21 February 2019; \\ Communicated by M. Taylor)
}

\begin{abstract}
Powdery mildew, caused by Blumeria graminis f. sp. hordei $(B g h)$ is a common foliar disease of barley worldwide. The creation of new cultivars with durable resistance to $B g h$ is highly desirable. This work was undertaken to examine the resistance to $B g h$ in 10 genetically diverse barley parents, and to evaluate their general combining ability (GCA) and specific combining ability (SCA) effects toward determining the genetic basis of disease resistance. Two experiments, in a growth chamber on seedling and in the field on adult plant stages, were conducted using a randomized complete block design with three replicates. The parents expressing differences in their reactions to $B g h$ were crossed in a half-diallel mating design to generate 45 full-sib families. Genetic component analysis showed significant effects for both GCA and SCA under both experiments suggesting that additive as well as non-additive genetic mechanisms were involved in the expression of resistance in these parents. The estimate of narrow-sense heritability was 0.63 and broad-sense heritability was 98\% indicating that selection for the disease resistance should be effective in these crosses. Resistant parents 'Banteng, PK 30-136 and 'Igri' had significantly negative GCA effects, suggesting their prime suitability for use in barley breeding programs to improve resistance to $B g h$.
\end{abstract}

Keywords: barley, powdery mildew, Blumeria graminis, partial resistance

\section{Introduction}

Powdery mildew caused by the obligate biotrophic fungus, Blumeria graminis f. sp. hordei $(B g h)$, is a global disease on barley (Hordeum vulgare L.) with potentially severe impact on yield (Murray and Brennan 2010). The development of cultivars with improved resistance has been a major breeding challenge for a long time, but successes are scarce. This is due to the lack of highly resistant genetic sources in cultivated barley, a limited knowledge of resistance mechanisms and a large diversity in the Bgh population (Rsaliyev et al. 2017).

Efforts to breed barley for resistance to $B g h$ have identified resistances that are expressed at seedling growth stages and that usually remain effective throughout the life of plant, and resistance that are effective at adult plant growth stages only (Aghnoum et al. 2010; Das and Griffey 1994). Previous works have demonstrated that the heritability to $\mathrm{Bgh}$ resistance ranged from low to high in the progeny of crosses between resistance and susceptible lines (Jørgensen 1994; Hickey et al. 2012; Spies et al. 2012). In addition, field 
observation of the disease prone to variability due to the time and intensity of infection, level of inoculum, genotype and environmental interactions make it impossible to obtain error-free estimates (Arabi and Jawhar 2012).

Never the less the success of plant breeding is based on the selection of suitable parents. The diallel analysis method is commonly used for parent selection (Mundt 2015). By this method, the genotypes used as parents have to be crossed in all possible combinations, which is a rather time and labor-consuming procedure. Moreover, the method provides information on the GCA of the parents SCA of the crosses (Dehghani et al. 2006). According to the combining ability test for different traits, high values of SCA indicate a higher share of gene dominance while high levels of GCA denote a higher share of additive effects of the genes controlling the traits in plants. If both GCA and SCA are insignificant, epistasis of genes has a profound influence in controlling the traits (Fehr 1993).

Experience suggests that the most cost-effective way to control Bgh is to develop resistant cultivars, although this may take considerable time. However, for effective implementation of Bgh resistance as a selection criterion in barley-breeding programs, genotypes representing a wide range of variation in response along with good yield and other agronomic characters need first to be tested for their suitability as parents. Such parental genotypes can be crossed to generate genetically diverse populations in which effective selection for high resistance might be accomplished. Therefore, knowledge about the inheritance of powdery mildew resistance will lead to amore efficient breeding strategy for durable resistance.

This study was conducted to estimate the GCA and SCA effects toward determining the genetic basis of $B g h$ resistance in a diallel cross program with 10 barley genotypes and their F1 hybrids.

\section{Materials and Methods}

\section{Greenhouse inoculation (seedling)}

The 10 barley genotypes used in this study were chosen for their reaction to $B g h$ from highly susceptible to highly resistant and for diverse origins (Table 1). The heterogeneous landrace Arabi Abiad was included in the experiments. The 10 genotypes were grown and crossed in our departmental isolated and controlled nursery plantings during the spring of the first season, in a diallel mating system without reciprocals to produce $45 \mathrm{~F} 1$ populations. The parents and their F1 crosses were sown in $20 \mathrm{~cm}$ pots filled with sterilized peat moss. The pots were all placed in a greenhouse and arranged in a randomized block design with three replicates at temperature $20-22{ }^{\circ} \mathrm{C}$ (day) and $16-18{ }^{\circ} \mathrm{C}$ (night) with a daylength of $16 \mathrm{~h}$ and a relative humidity of $85-95 \%$. Seedlings were irrigated with a nutrient solution consisted of: $1 \mathrm{~g} \mathrm{NaNO}_{3}, 0.25 \mathrm{~g} \mathrm{KNO}_{3}, 0.25 \mathrm{~g} \mathrm{MgSO}_{4} \cdot 7 \mathrm{H}_{2} \mathrm{O}, 0.25 \mathrm{~g}$ $\mathrm{KH}_{2} \mathrm{PO}_{4}$, and $0.05 \mathrm{~g} \mathrm{FeCL}_{3}$ per liter of water. At growth stage (GS) 11-12 (Zadoks et al. 1974), and in order to detect the seedling reaction to the same field population, seedlings of barley were placed for four nights in the field and the symptoms development was checked 10 days later and scored at GS 32. The experiment was repeated twice. 


\section{Field experiment (adult plant)}

For adult plant reaction scoring, field trials were conducted during two growing seasons under natural disease infection in Syria, at a site at $970 \mathrm{~m}$ altitude $(550 \mathrm{~mm}$ rainfall average). The location of the experiment was chosen to be favorable for the development of $B g h$, since the disease infects barley in this location annually. The parents and their F1 crosses were grown in a randomized complete block design with three replications. Each plot consisted of five rows, $25 \mathrm{~cm}$ apart and with 50 seeds sown per row. Soil fertilizers; $50 \mathrm{~kg} / \mathrm{ha}$ of nitrogen in the form of Urea $(46 \%)$ were drilled in equal portions before sowing and after tillering, and $27 \mathrm{~kg} /$ ha superphosphate $\left(33 \% \mathrm{P}_{2} \mathrm{O}_{5}\right)$ were drilled before sowing. The susceptible spreader cv. Golf was sown surrounding each replicate. In addition, powdery mildew infected stubble was distributed in the field when seedlings were at the second leaf stage and plants were wetted twice a day by applying water using a highpressure sprayer to enhance powdery mildew infection.

\section{Disease assessment}

At seedling (GS 32) and adult plant (GS 80) stages, mildew infections were scored according to the scale $0-100$ described by Moseman and Baenziger (1981) where; $0=$ no visible symptoms and $100=$ heavy sporulation and all the leaf area covered by a layer of $B g h$ mycelium. For each method, the mean value was used for analysis.

\section{Statistical analysis}

Statistical analyses were carried out using the STAT-ITCF program (Anonymous 1988). Analysis of variance (Newman-Keuls test) was performed to estimate the barley infection level in the greenhouse and field experiments. Combining ability analyses were conducted according to the Griffing's Method 2, Model 4 (1956). The additive $\left(\sigma^{2}{ }_{A}\right)$, nonadditive $\left(\sigma_{\mathrm{N}}^{2} \mathrm{~A}\right)$, and environmental $\left(\sigma_{\mathrm{E}}^{2}\right)$ variance were evaluated using mean squares for GCA (MSg), SCA (MSs), and error (MSE) from the analysis of variance table as outlined below.

$$
\sigma_{\mathrm{A}}^{2}=\left(\mathrm{MS}_{\mathrm{G}}-\mathrm{MSs}\right) /(\mathrm{P}+2) ; \sigma_{\mathrm{N}}^{2}=\mathrm{MSs}-\mathrm{MS}_{\mathrm{E}} ; \sigma_{\mathrm{E}}^{2}=\mathrm{Ms}_{\mathrm{E}}
$$

P: number of parents.

Broad-sense heritability $\left(h^{2}{ }_{\mathrm{b}}\right)$ and narrow-sense heritability $\left(h^{2}{ }_{\mathrm{n}}\right)$ estimates were evaluated as below.

$$
\begin{gathered}
h_{\mathrm{b}}^{2}=\left(\sigma_{\mathrm{A}}^{2}+\sigma_{\mathrm{N}}^{2}\right) /\left(\sigma_{\mathrm{A}}^{2}+\sigma_{\mathrm{N}}^{2}{ }_{\mathrm{A}}+\sigma_{\mathrm{E}}^{2}\right) \\
h_{\mathrm{n}}^{2}=\left(\sigma_{\mathrm{A}}^{2}\right) /\left(\sigma_{\mathrm{A}}^{2}+\sigma_{\mathrm{N}}^{2}+\sigma_{\mathrm{E}}^{2}\right)
\end{gathered}
$$

\section{Results}

The data showed significant differences $(P=0.05)$ among the 45 crosses for $B g h$ severity with values being consistently higher in susceptible genotypes, in both field and green- 
Table 1. Parental means (\%) and general combining ability (GCA) estimates for barley Bgh response undergreenhouse and field experiments

\begin{tabular}{|c|c|c|c|c|c|}
\hline \multirow{2}{*}{ Name } & \multirow{2}{*}{ Origin } & \multicolumn{2}{|c|}{ Severity } & \multicolumn{2}{|c|}{ GCA } \\
\hline & & Greenhouse & Field & Greenhouse & Field \\
\hline Golf & England & $82.67 \mathrm{a}$ & $79.67 \mathrm{a}$ & $12.0 *$ & $7.33 *$ \\
\hline Arrivate & USA & $69.67 \mathrm{bc}$ & $53.67 \mathrm{c}$ & $8.36^{*}$ & $4.68 *$ \\
\hline WI2291 & Australia & $56.0 \mathrm{~d}$ & $43.33 \mathrm{~d}$ & $6.86^{*}$ & $2.29 *$ \\
\hline 79-SIO-9 & Syria & $71.67 \mathrm{~b}$ & $72.17 b$ & $13.58^{*}$ & $13.37 *$ \\
\hline CI-5791 & Ethiopia & $66.67 \mathrm{c}$ & $33.33 \mathrm{e}$ & $9.53 *$ & 0.68 \\
\hline Furat1 & Syria & $43.67 \mathrm{e}$ & $44.33 d$ & 0.31 & $1.80^{*}$ \\
\hline Arabi Abiad & Syria & $39.67 \mathrm{e}$ & $38.00 \mathrm{e}$ & 0.99 & $6.52 *$ \\
\hline PK30-136 & Pakistan & $22.67 f$ & $16.33 \mathrm{f}$ & $-13.35^{*}$ & $-10.58 *$ \\
\hline Igri & Germany & $20.67 f$ & $18.5 \mathrm{f}$ & $-14.22 *$ & $-8.97 *$ \\
\hline Banteng & Germany & $1.33 \mathrm{~g}$ & $2.31 \mathrm{~g}$ & $-24.35^{*}$ & $-17.12^{*}$ \\
\hline LSD & & & & 1.76 & 1.01 \\
\hline
\end{tabular}

*Significant at $P=0.05$.

house experiments (Table 1). Moreover, symptoms that developed on greenhouse infected plants were similar to those observed under field conditions (data not shown).

The German genotype Banteng proved to be the most resistant one tested having $1.33 \%$ and $2.31 \%$ disease severity in greenhouse and field, respectively. However, levels of infected leaf area of between $16.33 \%$ and $22.67 \%$ were observed on Igri and PK 30 136 , respectively, while the remaining genotypes showed more severe symptoms. Considerably larger leaf infected area (more than 80\%) occurred on Golf (Table 1). A highly significant correlation in adult plant responses was found between the two seasons

Table 2. Mean sequare for general and specific combining ability (GCA and SCA) in a diallel analysis for barley Bgh response in F1 generation of barley grown under greenhouse (A) and field conditions (B)

\begin{tabular}{|l|c|c|c|}
\hline \multicolumn{5}{|c|}{ A } \\
\hline GCA & df & Mean & F1 \\
\hline SCA & 9 & 1349.86 & $206.19 * * *$ \\
\hline Error & 35 & 61.98 & $9.47 * *$ \\
\hline & 29 & 6.55 & $323.74 * * *$ \\
\hline GCA & 9 & B & $17.93 * * *$ \\
\hline SCA & 35 & 703.59 & \\
\hline Error & 29 & 28.98 & \\
\hline
\end{tabular}

*Significant at $P=0.05$. 
$(r=0.91, P=0.05)$, and no significant differences in barley responses (seedling and adult plant) were found between the two seasons, therefore the mean data are reported here.

Experiments performed on seedlings for Bgh resistance are usually sufficient for the needs of breeders and pathologists, but these tests do not necessarily predict the resistance of the adult plant (Czembor and Czembor 1998). Jones et al. (1981) and Das and Griffey (1994) found high values for additive and dominance variance, and dominance effects became greater in the adult plant.

The data showed that GCA and SCA effects were significant in F1, indicating that both effects were important in explaining variability for Bgh response in these crosses (Tables 2 and 3). This result implied that both additive and non-additive genetic mechanisms contributed significantly in the inheritance of $B g h$ resistance. The GCA mean square was around 18 times greater than SCA mean square in F1 generation (Table 2).

Table 3. Specific combining ability (SCA) estimates for barley Bgh response in the F1 generation from 10-parent diallel analysis in barley

\begin{tabular}{|c|c|c|c|c|c|}
\hline \multirow{2}{*}{ Hybrid No. } & \multirow{2}{*}{ Genotype } & \multicolumn{2}{|c|}{ Greenhouse } & \multicolumn{2}{|c|}{ Field } \\
\hline & & Mean & SCA & Mean & SCA \\
\hline 1 & Arabi Abiad $\times$ CI-5791 & 51.64 & -0.15 & 42.6 & $4.48^{*}$ \\
\hline 2 & Arabi Abiad $\times$ Banteng & 20.01 & 2.08 & 24.67 & $4.53 *$ \\
\hline 3 & Arabi Abiad $\times$ Igri & 28.01 & -0.04 & 25.58 & $-2.94 *$ \\
\hline 4 & Arabi Abiad $\times$ Furat 1 & 42.67 & 0.1 & 39.67 & 0.42 \\
\hline 5 & Arabi Abiad $\times$ Golf & 65.67 & $11.41^{*}$ & 48.33 & $3.56^{*}$ \\
\hline 6 & Arabi Abiad $\times$ X Arrivate & 52.01 & 1.038 & 38.33 & $-3.79 *$ \\
\hline 7 & Arabi Abiad $\times$ PK30-136 & 20.01 & $-8.91 *$ & 13 & $-13.87^{*}$ \\
\hline 8 & Arabi Abiad $\times$ WI2291 & 40.08 & $-9.05 *$ & 39.67 & -0.07 \\
\hline 9 & Arabi Abiad $\times$ 79-SIO-9 & 59.33 & 3.19 & 58.67 & $7.85^{*}$ \\
\hline 10 & CI-5791 $\times$ Banteng & 20.53 & $-5.92 *$ & 10.33 & $-4.14 *$ \\
\hline 11 & CI-5791 $\times$ gri & 28.17 & $-8.41 *$ & 22.43 & -0.19 \\
\hline 12 & CI-5791 × Furat 1 & 52.01 & 0.89 & 48.01 & $-14.60 *$ \\
\hline 13 & CI-5791 × Golf & 71.67 & $8.87 *$ & 33.33 & $-5.59 *$ \\
\hline 14 & CI-5791 $\times$ Arrivate & 73.67 & $14.27^{*}$ & 36.33 & 0.06 \\
\hline 15 & CI-5791 × PK30-136 & 18.33 & $-19.12 *$ & 10.33 & $-10.69 *$ \\
\hline 16 & CI-5791 × WI2291 & 65.33 & $7.67 *$ & 33.33 & -0.56 \\
\hline 17 & CI-5791 × 79-SIO-9 & 66.37 & 1.66 & 47.01 & 2.03 \\
\hline 18 & Banteng $\times$ Igri & 10.5 & $7.79 *$ & 3.97 & -0.85 \\
\hline 19 & Banteng $\times$ Furat 1 & 21.01 & 3.76 & 16.01 & 0.4 \\
\hline 20 & Banteng $\times$ Golf & 29.67 & 0.74 & 24.6 & $3.48^{*}$ \\
\hline 21 & Banteng $\times$ Arrivate & 24.01 & -1.29 & 21.73 & $3.25^{*}$ \\
\hline 22 & Banteng $\times$ PK30-136 & 5.33 & 1.75 & 8.01 & $4.78^{*}$ \\
\hline
\end{tabular}


Table 3 (cont.)

\begin{tabular}{|c|c|c|c|c|c|}
\hline \multirow{2}{*}{ Hybrid No. } & \multirow{2}{*}{ Genotype } & \multicolumn{2}{|c|}{ Greenhouse } & \multicolumn{2}{|c|}{ Field } \\
\hline & & Mean & SCA & Mean & SCA \\
\hline 23 & Banteng $\times$ WI2291 & 21.67 & -2.12 & 15.33 & -0.76 \\
\hline 24 & Banteng $\times 79-$ SIO-9 & 24.01 & $-6.80 *$ & 16.67 & $-10.50 *$ \\
\hline 25 & Igri $\times$ Furat1 & 22.67 & $-4.69 *$ & 19.33 & $-4.42 *$ \\
\hline 26 & Igri $\times$ Golf & 35.67 & -3.38 & 32.33 & $3.06^{*}$ \\
\hline 27 & Igri $\times$ Arrivate & 27.67 & $-7.74 *$ & 30.33 & $3.70^{*}$ \\
\hline 28 & Igri $\times$ PK30-136 & 17.67 & 3.97 & 16.97 & $5.60 *$ \\
\hline 29 & Igri $\times$ WI2291 & 47.67 & $13.76^{*}$ & 20.3 & $-3.94 *$ \\
\hline 30 & Igri $\times$ 79-SIO-9 & 39.67 & -1.26 & 35.3 & -0.02 \\
\hline 31 & Furat1 $\times$ X Golf & 55.33 & 1.75 & 45.33 & $5.28 *$ \\
\hline 32 & Furat $1 \times$ Arrivate & 45.67 & -4.27 & 29.17 & $-8.23 *$ \\
\hline 33 & Furat $1 \times$ PK 30-136 & 34.67 & $6.44 *$ & 21.53 & -0.62 \\
\hline 34 & Furat1 × WI2291 & 51.27 & 2.82 & 37.67 & 2.65 \\
\hline 35 & Furat $1 \times 79-$ SIO-9 & 48.67 & $-6.79 *$ & 36.01 & -10.10 \\
\hline 36 & Golf $\times$ Arrivate & 55.67 & $-5.96^{*}$ & 40.83 & -2.10 \\
\hline 37 & Golf $\times$ PK 30-136 & 38.99 & -0.93 & 25.5 & -2.17 \\
\hline 38 & Golf $\times$ WI2291 & 46.67 & $-13.47^{*}$ & 37.33 & $-3.21 *$ \\
\hline 39 & Golf $\times 79$-SIO-9 & 68.13 & 0.98 & 49.3 & -2.32 \\
\hline 40 & Arrivate $\times$ PK30-136 & 37.33 & 1.05 & 27.01 & 1.98 \\
\hline 41 & Arrivate $\times$ WI2291 & 60.67 & 4.17 & 41.67 & $3.78 *$ \\
\hline 42 & Arrivate $\times 79$-SIO-9 & 61.67 & -1.84 & 50.33 & 1.36 \\
\hline 43 & PK30 136 × WI2291 & 35.33 & 0.55 & 25.33 & $2.69 *$ \\
\hline 44 & PK30 × 79-SIO-9 & 57.01 & $15.20 *$ & 46.01 & $-12.28 *$ \\
\hline \multirow[t]{3}{*}{45} & WI2291 × 79-SIO-9 & 57.67 & -4.34 & 46.01 & -0.59 \\
\hline & Mean & 41.27 & & 30.92 & \\
\hline & LSD 0.05 & & 4.6 & & 2.66 \\
\hline
\end{tabular}

* Significant at $P=0.05$.

\section{Discussion}

The ten parental genotypes varied significantly between negative and positive GCA estimates (Table 3). However, negative values indicate a contribution towards $B g h$ resistance, while positive values represent the opposite. The GCA estimates of the parents were mainly associated with mean. Jones et al. (1981), and Das and Griffing (1994) and pointed out that GCA represents higher significance when it is highly correlated with parental means. The three most resistant parents Banteng, Igri and PK 30-136 had significantly 
negative GCA estimates in F1, and would be the most desirable parents to use in crosses to develop progenies with $B g h$ resistance. Since the success of selection in a population depends on additive variance and also because GCA is based on additive variance (Falconer 1981), it is possible to use the crosses obtained from parents with high GCA effects. As stated by Pesaraklu et al. (2016) and Ruckenbauer (1977) GCA effects are numerical values assigned to parents according to their average performance in cross combinations and serve as criterion for parental selection in breeding programs.

The magnitude of GCA and SCA mean square (Table 2) is indicative of the relative importance of additive and non-additive gene action in the inheritance of a trait (Dehghani et al. 2006). Hence, our findings suggest that additive genetic mechanisms were more important that non-additive ones in controlling resistance to $B g h$. This result is in agreement with those of Aghnoum et al. (2010), who found that resistance was quantitatively inherited in barley.

In addition, the estimate of broad-sense heritability was 0.98 , whereas narrow-sense heritability was estimated at 0.63 in F1. These results suggest that additive gene actions were primarily responsible for the inheritance of resistance to $B g h$ in these crosses. The levels of heritability for resistance to $B g h$ observed in this study suggest that effective selection for resistance can be achieved for the crosses made here.

In this work, the predominance of GCA effects indicates that resistance to Bgh can be improved through selection. Moreover, parents with a high level of resistance and significant negative GCA estimates were identified. Resistant parents 'Banteng, and 'Igri' had significantly negative GCA effects, and they likely are superior sources for $B g h$ resistance for use in barley-breeding programs. In addition, this study suggests that artificial seedling inoculation under controlled conditions can provide consistent information on barley response, and reliable host reaction data could be obtained through speed up the breeding process by allowing multiple cycles of screening and selection in 1 year.

\section{Acknowledgements}

We thank the Director General of AECS and the Head of Molecular biology and Biotechnology Department for their much appreciated help throughout the period of this research.

\section{References}

Aghnoum, R., Marcel, T.C., Johrde, A., Pecchioni, N., Schweizer, P., Niks, R.E. 2010. Basal host resistance of barley to powdery mildew: connecting quantitative trait Loci and candidate genes. Mol. Plant Microbe Interact. 23:91-102.

Anonymous, 1988. STAT-ITCF, programme, MICROSTA, realized by ECOSOFT, 2 ${ }^{\text {nd }}$ Version. Institut Technique des Cereals et des Fourages, Paris pp. 55.

Arabi, M.I.E., Jawhar, M. 2012. Expression of resistance to Blumeria graminis in barley genotypes (Hordeum vulgare L.) under field and controlled conditions. J. Plant Biol. Res. 1:107-112.

Czembor, J.H., Czembor, H.J. 1998. Powdery mildew resistance in cultivars of spring barley from Polish Register. Plant Breed. 42:87-99.

Das, M.K., Griffey, G.A. 1994. Diallel analysis of adult plant resistance to powdery mildew in wheat. Crop Sci. 34:948-952. 
Dehghani, H., Torabi, M., Moghadam, M., Ghanadha, M.R. 2006. Cross-plot analysis of bi plot-type allele of yellow rust of wheat. J. Seed Plant 21:123-138.

Fehr, W.R. 1993. Principles of Cultivar Development. Vol. 1. MacMillan Publ. Co. New York, USA.

Griffing, B. 1956. Concept of general and specific combining ability in relation to diallel crossing systems. Aust. J. Biol. Sci. 9:463-493.

Hickey, L. T. et al. 2012. Mapping quantitative trait loci for partial resistance to powdery mildew in an Australian barley population. Crop Sci. 52:1021-1032.

Jones, I.T., Sethar, H., Davies, L.J.E.R. 1981. Genetics of partial resistance to barley powdery mildew. In: Barley Genetics IV. Proc $4^{\text {th }}$ Int Barley Genet Symp Edinburgh, pp. 449-457.

Jorgensen, J.H. 1994. Genetics of powdery mildew resistance in barley. Crit. Rev. Plant Sci. 13:97-119.

Moseman, J.G., Baenziger, P.S. 1981. Genes conditioning resistance of Hordeum spontaneum to Erysiphe graminins f. sp. Hordi. Crop Sci. 21:229-232.

Mundt, C.C. 2015. Durable resistance: a key to sustainable management of pathogens and pests. Infect. Genet. Evol. 27:446-455.

Murray, G.M., Brennan, J.P. 2010. Estimating disease losses to the Australian barley industry. Australas. Plant Path. 39:85-96.

Pesaraklu, S., Soltanloo, H., Ramezanpour, S.S., Kalate, A.M., NejadGhomi, N.A.A. 2016. An estimation of the combining ability of barley genotypes and heterosis for some quantitative traits. Iran Agri. Res. 35:7380.

Rsaliyev, A., Pahratdinova, Z., Rsaliyev S. 2017. Characterizing the pathotype structure of barley powdery mildew and effectiveness of resistance genes to this pathogen in Kazakhstan. The Author(s) BMC Plant Biol. 17(Suppl 1):178.

Ruckenbauer, D. 1977. Vergleichende Untersuchungen über die Einsatzmöglichkeiten neuer biometrischer Methoden in der Kreuzungszüchtung bei Winterweizen. I. Teil. Die Bodenkultur 28:58-93.

Spies, A. et al. 2012. Allele mining in barley genetic resources reveals genes of race-non-specific powdery mildew resistance. Front. Plant Sci. 2:1-22.

Zadoks, J.C., Chang, T.T., Konzak, C.F. 1974. A decimal code for the growth stages of cereals. Weed Res. 14:415-421. 